\title{
PENERAPAN MEDIA AUDIO VISUAL UNTUK MENINGKATKAN HASIL BELAJAR GERAK DASAR POLA LANGKAH PENCAK SILAT SEKOLAH DASAR
}

\author{
Pongky Widyalaksono $^{1 \square}$, Hendra Mashuri ${ }^{2}$, Septyaning Lusianti ${ }^{3}$ \\ Universitas Nusantara PGRI Kediri \\ pongkyputra@gmail.com

\section{Info Artikel} \\ Sejarah Artikel: \\ Diterima: April-2020 \\ Disetujui: Mei-2020 \\ Dipublikasikan : Juni-2020 \\ Kata Kunci: \\ audiovisual, hasil belajar, gerak \\ dasar, pola langkah, pencak silat \\ Tujuan penelitian ini untuk mengetahui penerapan media audiovisual dalam \\ meningkatkan hasil belajar gerak dasar pola langkah pencak silat. Penelitian \\ ini merupakan action research. Subjek penelitian ini adalah kelas V di SD \\ Negeri Banjaran 2 Kediri Tahun Ajaran 2019/2020 yang berjumlah 39 siswa. \\ Instrumen penelitian ini adalah lembar observasi siswa dan guru, tes uraian \\ dan tes praktik. Hasil penelitian ini menunjukkan terjadi peningkatan hasil \\ belajar gerak dasar pola langkah pencak silat setelah penerapan pembelajaran \\ dengan menggunakan media audiovisual. Dengan demikian dapat \\ disimpulkan bahwa penerapan media audiovisual dapat meningkatkan hasil \\ belajar gerak dasar pola langkah pencak silat pada siswa sekolah dasar.
}

\section{Abstract}

The purpose of this study was to determine the application of audiovisual media in improving the learning outcomes of the basic motion patterns of pencak silat steps. This research is a Classroom Action Research. The subject of this research was class V at Banjaran 2 Kediri Elementary School in 2019/2020 Academic Year with a total of 39 students. The instruments of this study were student and teacher observation sheets, description tests and practice tests. The results of this study indicate an increase in learning outcomes of the basic motion patterns of pencak silat steps after the application of learning using audiovisual media. Thus it can be concluded that the application of audiovisual media can improve learning outcomes of the basic motion patterns of pencak silat steps in elementary school students.

(C) 2020 Universitas Negeri Malang 


\section{PENDAHULUAN}

Secara kongkrit, pendidikan jasmani berupaya untuk membuat peserta didik sehat seutuhnya. Proses pendidikan jasmani dan olahraga mengandung unsur perkembangan jasmani yang membantu perkembangan kognisi serta membiasakan peserta didik untuk mengamalkan nilai-nilai luhur yang diwujudkan dalam gaya hidup peserta didik (Mashuri, Puspitasari, \& Abadi, 2019). Keberhasilan dalam pembelajaran (pendidikan jasmani) tergantung pada proses interaksi yang diawali dengan persepsi pelaku pendidikan, yaitu siswa dan guru terhadap proses belajar mengajar pendidikan jasmani (Mashuri, 2017).

Proses pendidikan jasmani selalu melibatkan guru untuk memberikan aktifitas fisik yang menyenangkan dan mampu mengembangkan kemampuan jasmani siswa. Oleh sebab itu guru pendidikan jasmani harus bisa mengemas materi pendidikan jasmani dengan permainan atau metode pembelajaran yang memberikan kegembiraan dan kepuasan kepada siswa (Mashuri, 2019).

Dalam pembelajaran, guru sebagai pelaku dalam proes belajar mengajar, karena gurulah yang mengarahkan bagaimana proses belajar mengajar itu dilaksanakan, guru harus inovatif dalam menggunakan strategi pembelajaran, agar menjadi lebih efektif juga menarik sehingga bahan pelajaran yang disampaikan akan membuat siswa merasa senang dan merasa perlu untuk mempelajari bahan pelajaran tersebut dan siswa dapat mengembangkan potensi yang dimilki.

Agar dapat menghidupkan suasana dalam kelas dan dapat menarik perhatian siswa, guru dapat menggunakan media pembelajaran yang sesuai. Menurut Sudjana (2006) media pembelajaran harus dapat dipergunakan untuk mengeluarkan pesan dan dapat merangsang pikiran, dapat membangkitkan semnagat, perhatian dan kemauan siswa sehingga dapat mendorong terjadinya proses pembelajaran pada diri siswa. Media merupakan alat yang dapat digunakan sebagai perantara dalam menstimulasi semua aspek perkembangan pada anak usia dini baik aspek nilai moral dan agama, aspek fisik motorik, aspek bahasa, aspek sosial emosional, aspek kognitif maupun aspek seni (Dewi \& Herman, 2017). Media pembelajaran dipergunakan untuk memudahkan dalam penyampaian materi ke peserta didik (Jatmika, 2005). Dari pendapat tersebut, dapat disimpulkan bahwa peran media pembelajaran sangat penting untuk membantu guru dalam melaksanakan pembelajaran dan media pembelajaran merupakan saluran atau sarana untuk menyampaikan suatu pesan atau informasi didalam proses belajar yang dicapai.

Pendidikan jasmani materi pencak silat merupakan materi yang diajarkan mengingat banyak perguruan silat di lingkukan SDN Banjaran 2 Kediri. Materi pencak silat menempati posisi yang strategis karena banyak siswa yang berminat belajar pencak silat. Oleh sebab itu, pendidikan melalui pencak silat merupakan cara yang tepat untuk menguatkan karakter siswa. Pendidikan pencak silat dapat mengembangkan lima nilai karakter yang khas yakni karakter taqwa, Tangguh, trengginas, tanggap, dan tanggon (Mulyana, 2014). Pengembangan karakter dalam pencal silat harus diiluti dengan pengembangan gerakan yang baik dan benar. Dasar gerakan dalam pencak silat adalah pola langkah. Pola langkah merupakan fundamental gerakan dalam pencak silat, artinya pola langkah yang baik dan benar akan menjadi fundamen gerak dasar dan pengembangannya.

Pencak silat merupakan keterampilan dan ilmu tentang pola gerak bertenaga yang efektif, indah, dan menyehatkan tubuh, yang dijiwai budi pekerti luhur berdasarkan ketaqwaan kepada Tuhan Yang Maha Esa, serta bertujuan untuk membentuk pertahanan diri dan memupuk rasa tanggung jawab sosial (Kurniawan, 2018). Melalui belajar gerak yang bertenaga dan indah, materi pencak silat mampu menumbuhkan jiwa spiritual yang tinggi serta jasmani yang kuat.

Pencak silat sebagai wahana pendidikan sarat akan nilai-nilai luhur yang meliputi aspek mental spiritual, aspek olahraga, aspek seni, dan aspek beladiri (Muhtar, 2017). Nilai-nilai luhur tersebut menjadi satu padu dalam diri pesilat. Oleh sebab itu pendidikan dengan materi pencak silat harus ditanamkan kepada anak pada sekolah dasar. Siswa sekolah dasar yang mempelajari dan menguasai pencak silat akan mampu menjadi manusia yang tanggung secara jasmani, rohani, sosial, dan spiritual.

Nilai-nilai luhur dalam pencak silat akan tercapai dengan pembelajaran dari dasar, yaitu pola langkah gerak yang baik, benar, harmonis, dan sepenuh jiwa. Pola langkah merupakan dasar dari semua gerakan dalam pencak silat. Artinya pola langkah memberikan pondasi sebagai pengembangan gerakan lain. Apabila terjadi kesalahan dalam pola langkah gerak, maka bisa dipastikan tidak akan terbentuk gerakan yang baik dan benar. Oleh sebab itu, pembelajaran pencak silat pola langkah harus benar-benar dikuasai oleh siswa.

Hasil observasi di SD Negeri Banjaran 2 Kediri selama bulan April 2019 ditemukan fakta bahwa proses belajar mengajar (PBM) kelas V pada mata pelajaran pendidikan jasmani khususya pada 
pembelajaran pencak silat yang kurang sesuai dianggap menjadi faktor utama rendahnya hasil belajar siswa khususnya gerak dasar pola langkah pencak silat. Hal ini terbukti masih banyaknya siswa yang belum mampu melakukan dan menggunakan gerak dasar pola langkah pencak silat seperti posisi tangan yang salah, sikap badan yang kurang tepat, gerakan kaki yang keliru, dan pandangan yang kurang fokus.

Dari kenyataan di atas, perlu adanya upaya untuk memperbaiki mutu dan kualitas dalam suatu proses pembelajaran yang merupakan tanggung jawab seorang guru. Salah satunya melalui penerapan media audiovisual dalam pembelajaran pendidikan jasmani. Menurut Ginting (2010) tentang media audiovisual yaitu, media pembelajaran yang menyajikan audio dan visual yang berisi pesan-pesan pembelajaran baik yang berisi konsep, prinsip, prosedur, teori aplikasi pengetahuan untuk membantu pemahaman terhadap suatu materi pembelajaran. Media audio visual memberikan konsistensi gerak dari sebuah pemodelan dan menampilkan akurasi gerak yang $100 \%$ walaupun diulang-ulang (Santoso, 2016).

Media audio visual terdiri dari media audio dan media visual. Media audio merupakan media pembelajaran melalui suara yang mengharuskan siswa mendengarkan dan membayangkan deskripsi suara. Media visual merupakan media pembelajaran menggunakan gambar yang mengharuskan siswa melihat dan membayangkan dirinya sebagai gambar dalam beraktifitas fisik. Media audio visual meripakan media pembelajaran yang menggabungkan media suara dan gambar diam atau gerak. Media audio visual biasanya berupa video yang dibuat agar siswa berimajinasi dirinya bergerak (belajar gerak) dengan gambar yang dilihat dan suara yang penjadi petunjuk gerakannya. Jadi dapat disimpulkan media audiovisual merupakan salah ${ }^{-}$satu media yang dapat digunakan untuk pembelajaran olahraga yang dapat digunakan untuk memperjelas banyak hal seperti gerak dasar pola langkah pencak silat.

Media audiovisual ini memiliki kelebihan yaitu dapat menyajikan obyek dan peristiwa nyata di kelas untuk dijadikan bahan pembahasan atau diskusi yang menarik. Penggunaan media audiovisual guru dapat menampilkan beberapa video terkait gerak dasar pola langkah pencak silat, sehingga siswa dapat memperhatikan dengan seksama gerakan tersebut. Hal ini dikarenakan dalam materi gerak dasar pola langkah pencak silat masih banyak para siswa yang kurang menguasai gerak dasar pola langkah pencak silat dengan baik dan benar. Seperti pengalaman waktu mengajar siswa kelas V di SD Negeri Banjaran 2 Kediri, banyak ditemukan siswa belum mampu melakukan dan menggunakan gerak dasar pola langkah pencak silat seperti melakukan gerakan kuda-kuda yang kurang sempurna, langkah kaki yang masih keliru dan gerak langkah dalam pencak silat yang kurang paham.

\section{METODE}

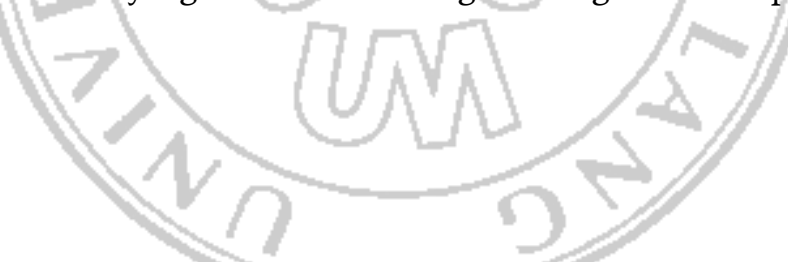

Penelitian ini merupakan action research yang terdiri dari satu siklus, dimana model dari penelitian ini mengambil model penelitian tindakan dari Kemmis dan Mc Taggart yaitu berbentuk spiral, dalam satu siklus meliputi perencanaan, pelaksanaan tindakan, pengamatan dan refleksi. Penelitian ini dilaksanakan selama lima minggu dengan rincian, minggu pertama untuk melakukan pretest, minggu ke dua untuk melakukan pembelajarn audiovisual di dalam kelas. Minggu ketiga dan keempat untuk melakukan pembelajaran praktik di lapangan. Minggu kelima untuk melaksanakan posttest.

Subjek penelitian ini adalah siswa kelas V SD Negeri Banjaran 2 Kediri Tahun pelajaran 2019/2020 yang berjumlah 39 siswa terdiri dari 20 siswa laki-laki dan 19 siswa perempuan. Teknik pengumpulan data penelitian ini menggunakan tes dan lembar observasi. Tes terdiri dari dua yaitu tes pengetahuan dan tes keterampilan (praktik). Ada dua observasi yang dilakukan yaitu observasi terhadap guru dan observasi terhadap siswa Metode analisa yang digunakan adalah analisa deskriptif.

\section{HASIL}

Terdapat lima tahapan dalam penelitian ini, yaitu tahap perencanaan, pelaksanaan tindakan, pengamatan dan refleksi. 


\section{Perencanaan}

Perencanaan meliputi pembuatan RPP, lembar observasi guru dan siswa, instrument tes pengatahuan, lembar penilaian tes pengetahuan dan praktik gerak dasar pola langkah pencak silat. RPP dibuat berdasarkan acuan kurikulum yang digunakan sekolah, yaitu KTSP berbasis kearifan lokal yang disesuaikan dengan karakter peserta didik. Lembar observasi disusun sesuai langkah-langkah pembelajaran guru yang digunakan untuk menilai proses pengajaran oleh teman sejawat. Pemilihan instrument tes pengetahuan dan tes praktik berdasarkan kesepakatan guru penjas di SD Negeri Banjaran 2 Kediri dan tim MGPM Kota Kediri.

\section{Pelaksanaan tindakan}

Pelaksanaan pembelajaran dilakukan selama empat minggu yaitu pada minggu pertama memberikan pengenalan materi dan metode serta memahami kemampuan dan pengetahuan awal peserta didik di kelas, minggu kedua melaksanakan pembelajaran menggunakan media audiovisual di dalam kelas. Pada minggu ketiga dan keempat melaksanakan pembelajaran gerak pola langkah di lapangan. Adapun pelaksanaan tindakan dapat dilihat pada tabel 1.

Tabel 1. Jadwal Kegiatan Penelitian

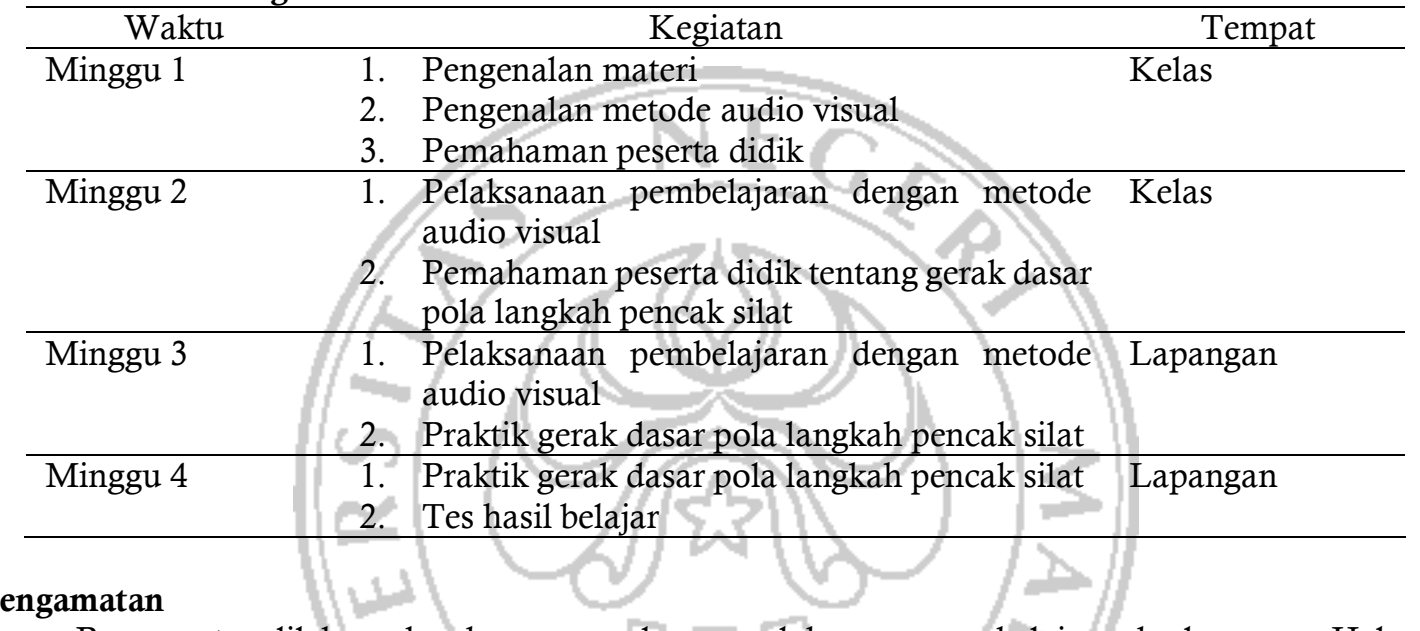

Pengamatan dilaksanakan bersamaan dengan pelaksanaan pembelajaran berlangsung. Hal yang perlu diamati adalah mengamati aktifitas pembelajaran terutama aktivitas siswa dan guru. Berdasarkan hasil pengamatan aktifitas guru sebelum menggunakan media audiovisual menunjukkan bahwa aktifitas pembelajaran guru 75,5\% masuk pada kriteria cukup dan setelah setelah menggunakan media audiovisual menunjukkan bahwa aktifitas guru 93,3\% masuk pada kriteria baik.

Berdasarkan observasi aktifitas siswa sebelum menggunakan media audiovisual dapat diketahui bahwa nilai kerjasama peserta didik 81 (average 2,08), nilai keaktifan peserta didik 76 (average 1,95), nilai partisipasi peserta didik 77 (average 1,97), dan nilai inisiatif peserta didik 74 (average 1,9). Setelah diberikan perlakuan, nilai kerjasama peserta didik menjadi 119 (average 3,05), nilai keaktifan peserta didik 120 (average 3,08), nilai partisipasi peserta didik 120 (average 3,08), dan nilai inisiatif peserta didik 119 (average 3,05). Persentase peningkatan komponen kerjasama 32\%, komponen keaktifan $37 \%$, komponen partisipasi 36\%, dan komponen inisiatif 38\%. Secara rinci dapat dilihat pada tabel 2.

Tabel 2. Penghitungan Per Komponen Nilai Afektif

\begin{tabular}{|c|c|c|c|c|c|c|c|c|c|c|c|c|}
\hline & \multicolumn{3}{|c|}{ Kerja sama } & \multicolumn{3}{|c|}{ Keaktifan } & \multicolumn{3}{|c|}{ Partisipasi } & \multicolumn{3}{|c|}{ Inisiatif } \\
\hline & Jumlah & $\%$ & Avr. & Jumlah & $\%$ & Avr. & Jumlah & $\%$ & Avr. & Jumlah & $\%$ & Avr. \\
\hline Pre-Test & 81,00 & & 2,08 & 76,00 & & 1,95 & 77,00 & & 1,97 & 74,00 & & 1,90 \\
\hline Post-Test & 119,00 & & 3,05 & 120,00 & & 3,08 & 120,00 & & 3,08 & 119,00 & & 3,05 \\
\hline $\mathrm{D}$ & 38,00 & 32 & 0,97 & 44,00 & 37 & 1,13 & 43,00 & 36 & 1,10 & 45,00 & 38 & 1,15 \\
\hline
\end{tabular}

Data perbandingan hasil penghitungan per komponen nilai afektif dapat dilihat secara sederhana pada bagan 1 . 


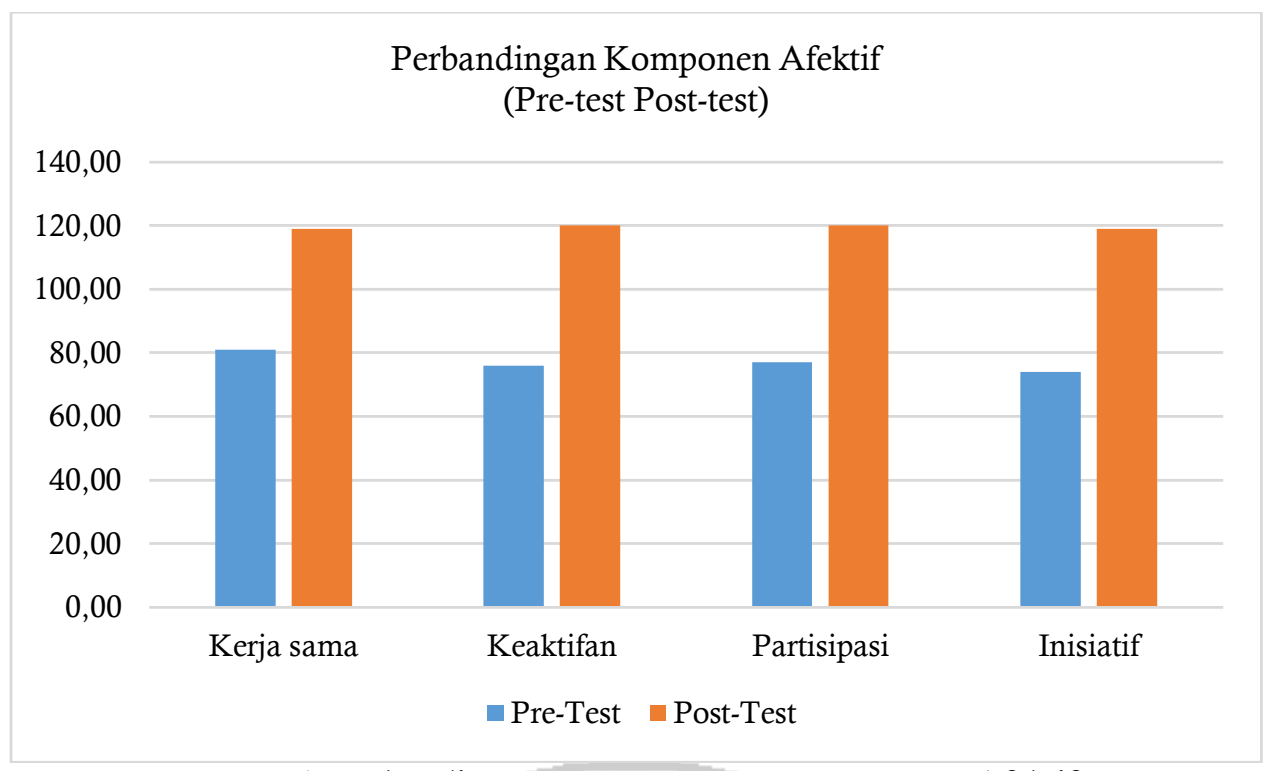

Bagan 1. Perbandingan Pre-test Post-test Komponen Afektif

Secara keseluruhan komponen afektif sebelum perlakuan media audio visual, nilai peserta didik untuk penilaian afektif peserta didik adalah 308 (average 7,9). Setelah diberi perlakuan nilai afektif peserta didik adalah 478 (average 12,26). Persentase peningkatan nilai afektif peserta didik adalah $36 \%$. Secara rinci data keseluruhan nilai afektif peserta didik dapat dilihat di tabel 3.

\section{Tabel 3. Penghitungan Nilai Afektif}

\begin{tabular}{l|ccc} 
& & & \\
$\mathrm{N}=39$ & Pre-Test & Post-Test & $\mathrm{D}$ \\
\hline Mean & 49 & 77 & 27 \\
\hline Jumlah & 1925 & 2988 & 1063 \\
\hline Varian & 67,4237 & 79,60105 & 15,393 \\
\hline SD & 8,21119 & 8,921942 & 3,9234 \\
\hline Max & 69 & 94 & 31 \\
\hline Min & 38 & 56 & 19 \\
\hline$\%$ & & & $36 \%$ \\
\hline
\end{tabular}

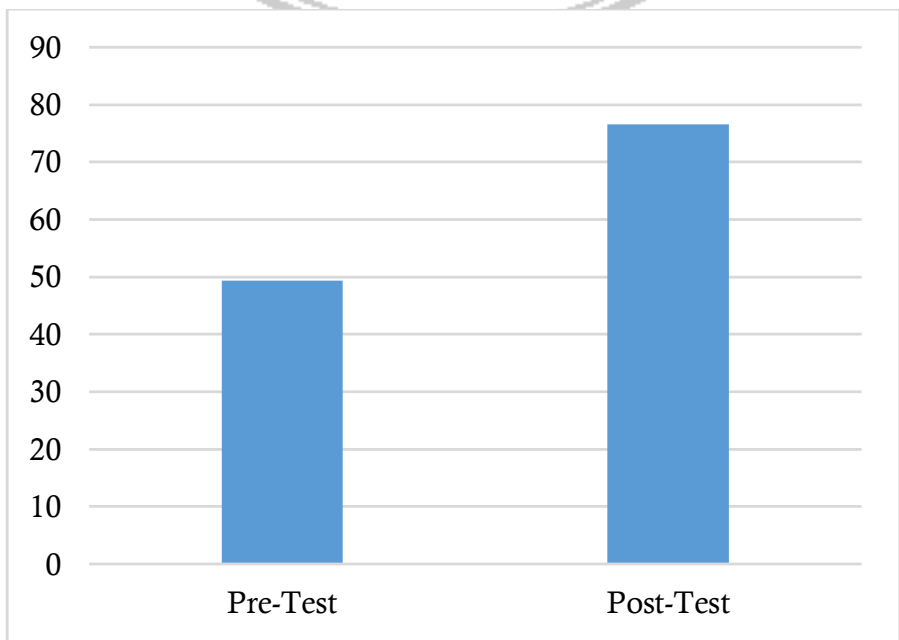

Bagan 2. Perbandingan Pre-Test dan Post-Test Nilai Afektif 
Berdasarkan hasil tes pengetahuan tentang gerak dasar pola langkah pencak silat sebelum menggunakan media audiovisual rata-rata nilai peserta didik sebesar 65,9. Setelah diberikan metode belajar audio visual, terjadi peningkatan rata-rata nilai praktik siswa menjadi 82,44. Persentase peningkatan tersebut sebesar $20 \%$. Hal ini menunkukkan bahwa media audio visual mampu memberikan gambaran nyata tentang gerak dasar pola langkah pencak silat serta bisa membuat perserta didik tertarik dan membayangkan gerakannya. Merangsang kemampuan berfikir anak akan meningkatkan pengetahuan anak tentang gerak dasar pola langkah pencak silat. Berdasarkan hasil pengamatan, beberapa peserta didik juga melakukan diskusi tentang tata cara gerakan, fungsi gerakan, bahkan sampai pengembangan gerakan. Secara rinci data nilai tes pengetahuan peserta didik dapat dilihat di tabel 4 dan bagan 3 .

Tabel 4. Perbandingan Nilai Pre-test dan Post-Test Nilai Pengetahuan

\begin{tabular}{|c|c|c|c|}
\hline & Pre-Test & Post-Test & $\mathrm{D}$ \\
\hline Mean & 65,90 & 82,44 & 16,54 \\
\hline Jumlah & 2570 & 3215 & 645 \\
\hline Var & 51,15 & 72,20 & 109,41 \\
\hline SD & 7,15 & 8,50 & 10,46 \\
\hline$\%$ & & & $20 \%$ \\
\hline \multicolumn{4}{|l|}{90,00} \\
\hline \multicolumn{4}{|l|}{80,00} \\
\hline \multicolumn{4}{|l|}{70,00} \\
\hline \multicolumn{4}{|l|}{60,00} \\
\hline \multicolumn{4}{|l|}{50,00} \\
\hline \multicolumn{4}{|l|}{40,00} \\
\hline \multicolumn{4}{|l|}{30,00} \\
\hline \multicolumn{4}{|l|}{20,00} \\
\hline \multicolumn{4}{|l|}{10,00} \\
\hline \multicolumn{4}{|l|}{0,00} \\
\hline & est & Post-' & \\
\hline
\end{tabular}

Bagan 3. Perbandingan Nilai Pre-Test dan Post-Test Nilai Pengetahuan

Berdasarkan hasil tes praktik sebelum menggunakan media audiovisual rata-rata nilai praktik peserta didik sebesar 61,85 . Setelah diberikan metode belajar audio visual, terdadi peningkatan ratarata nilai praktik siswa menjadi 82,36 . Persentase peningkatan tersebut sebesar $25 \%$. Hal ini menunkukkan bahwa media audio visual memberikan dampak yang baik untuk merangsang daya imajinasi peserta didik dan mampu mendorong siswa untuk bersemangat mempraktikkan. Berdasarkan hasil pengamatan, beberapa siswa juga saling membelajarkan Teknik dasar pola langkah kepada teman lainnya. Diskusi ringan antar peserta didik tentang tahapan-tahapn teknik dasar pola langkas juga sering dilakukan pserta didik. Secara rinci data nilai tes praktik peserta dapat dilihat di tabel 5 dan bagan 4 .

Tabel 5. Perbandingan Nilai Pre-test dan Post-Test Nilai Praktik

\begin{tabular}{lccc} 
& Pre-Test & Post-Test & D \\
\hline Jumlah & 2412 & 3212 & 800 \\
\hline Mean & 61,85 & 82,36 & 20,51 \\
\hline Varian & 15,87 & 57,87 & 63,31 \\
\hline SD & 3,98 & 7,61 & 7,96 \\
\hline$\%$ & & & $25 \%$ \\
\hline
\end{tabular}




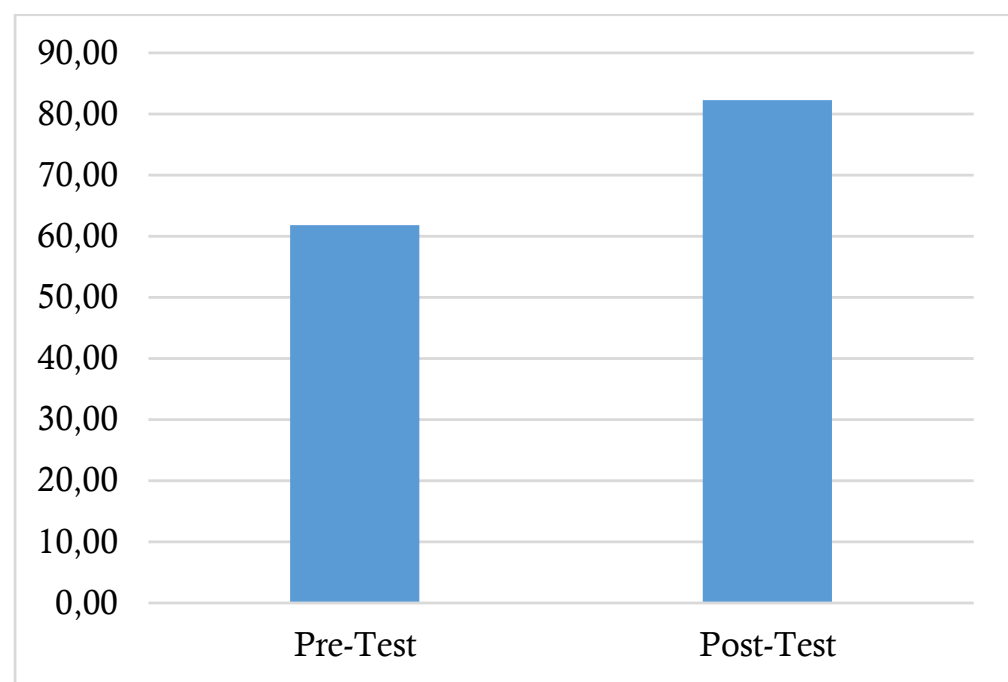

Bagan 4. Perbandingan Nilai Pre-Test dan Post-Test Nilai Praktik

Secara keseluruhan hasil belajar gerak dasar pola langkah pencak silat peserta didik sebelum dilakukan metode audio visual didapatkan nilai-rata-rata 59. Setelah mendapatkan pembelajaran dengan metode audio visual, rata-rata nilai hasil belajar siswa menjadi 80 dan masuk dalam KKM sekolah (75). Persentase peningkatan hasil belajar teknik dasar pola langkah pencak silat adalah $27 \%$. Hasil tersebut menunjukkan bahwa penerapan metode audio visual dalam pemebelajaran penjas materi gerak dasar pola langkah pencak silat mampu meningkatkan pengetahuan, keterampilan dan pengatan karakter peserta didik. Secara rinci hasil analisis data hasil belajar peserta didik pada tabel 5 dan bagan 5 .

Tabel 6. Hasil Belajar Gerak Dasar Pola Langkah Pencak Silat

\begin{tabular}{l|cccc} 
& & Pre-Test & Post-Test & D \\
\hline Mean & 59 & 80 & 21 \\
\hline Jumlah & 2302 & 3138 & 836 \\
\hline Varian & 18,2945 & 63,95421 & 36,697 \\
\hline SD & 4,27721 & 7,997138 & 6,0578 \\
\hline Max & 70 & 94 & 31 \\
\hline Min & 52 & 62 & 4 \\
\hline$\%$ & & & $27 \%$ \\
\hline
\end{tabular}




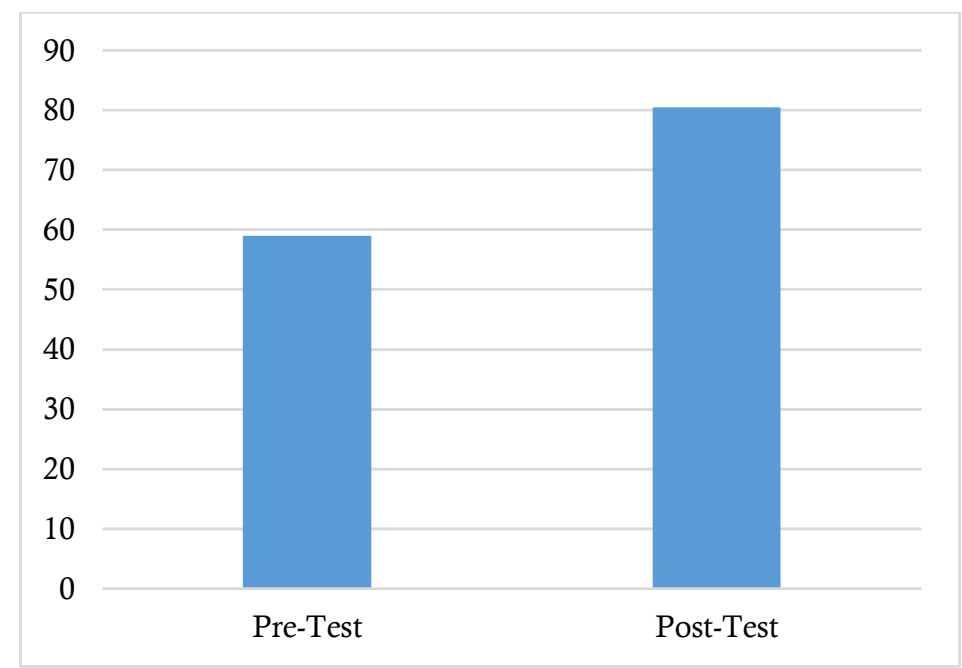

Bagan 5. Perbandingan Hasil Belajar Pre-Test dan Post-Test

\section{Refleksi}

Pada tahap refleksi, peneliti telah berdiskusi dengan pengamat (teman sejawat) untuk mengkaji semua temuan, baik kekurangan maupun kelebihan selama proses pembelajaran yang dijadikan dasar untuk menyusun dan melaksanakan perbaikan pembelajaran. Dari hasil penelitian diperoleh bahwa dari hasil observasi aktivitas kegiatan pembelajaran yang dilakukan guru terjadi peningkatan dimana sebelumnya cara penerapan pembelajaran guru masuk kategori cukup meningkat menjadi baik. Selain itu dari hasil penilaian aktifitas siswa juga terjadi peningkatansebesar $36 \%$.

Pada ranah kognitif siswa juga terjadi peningkatan hasil belajar yaitu sebelum menggunakan media audiovisual rata-rata hasil belajar siswa sebesar 65,9 . Rata-rata tersebut di bawah nilai KKM yang ditentukan yaitu 75 . Sedangkan setelah menggunakan media audiovisual rata-rata hasil belajar sebesar 82,44. Rata-rata tersebut di atas nilai KKM yang ditentukan.

Pada ranah psikomotor terjadi peningkatan hasil belajar gerak pola langkah pencak silat setelah diterapkannya media audiovisual. Berdasarkan hasil pengamatan, peningkatan nilai psikomotor dilepas dari peran guru yang membimbing peserta didik selama proses pembelajaran dengan metode audio visual. Guru juga mempraktekkan gerakan dan membantu peserta didik dalam mempraktekkan gerakan. Guru juga terbuka dalam sesi tanya jawab mengenai gerakan dan pengembangan gerakan hasil dari imajinasi peserta didik.

Baik dari aspek kognitif, afektif maupun psikomotor menunjukkan bahwa terjadi peningkatan hasil belajar gerak dasar pola langkah pencak silat. Peningkatan hasil belajar tersebut sudah melebihi KKM yang ditentukan oleh Lembaga, yaitu 7,5. Hal ini membuktikan bahwa metode audio visual mampu meningkatkan hasil belajar siswa SD pada materi gerak dasar pola langkah pencak silat. Kondisi ini harus dipertahankan dan ditingkatkan lagi. Oleh karena itu, perbaikan pembelajaran gerak dasar pola langkah pencak silat berakhir pada siklus I.

\section{PEMBAHASAN}

Penerapan media audiovisual dapat meningkatkan hasil belajar gerak dasar pola langkah pencak silat pada siswa kelas V di SD Negeri Banjaran 2 Kediri Tahun Ajaran 2019/2020. Hal ini dibuktikan dari hasil tes pengetahuan, tes praktek dan observasi afektif peserta didik, menunjukkan terjadi peningkatan hasil belajar siswa. Selain itu dari hasil observasi aktivitas guru dalam mengajar juga nampak terjadinya peningkatan pembelajaran. Hal ini dikarenakan penggunkaan media audio visual mampu memudahkan guru dalam menjelaskan gerak pola langkah pencak silat dan siswa juga lebih mudah memahami penjelasan dari guru. Sehingga pada saat pembelajaran di lapangan siswa lebih mudah untuk mempraktikkan gerakan pola langkah yang benar. Media pembelajaran mampu menjadikan pembelajaran lebih menarik sehingga siswa tidak merasa jenuh, pesan dan informasi menjadi lebih jelas serta mampu memanipulasi dan menghadirkan objek yang sulit dijangkau oleh siswa. 
Hasil penelitian ini sesuai dengan pernyataan Wati (2016) bahwa media audio visual memiliki kelebihan yaitu bisa menarik perhatian dari periode yang singkat dari rangsangan lainnya. Hasil observasi guru dan teman sejawat menunjukkan bahwa peserta didik tertarik dengan tampilan yang ditunjukkan dengan efek suara yang sesuai dengan gerakan yang diajarkan. Sebagian besar penonton dapat memperoleh informasi dari ahli atau spesialis. Peserta didik merasa apa yang dilihat dan dicermati merupakan pembelajaran dari seorang ahli sehingga peserta didik merasa belajar langsung dari ahli pencak silat. Demonstrasi yang sulit bisa dipersiapkan dan direkam sebelumnya sehingga dalam waktu mengajar guru bisa memusatkan perhtian dan penyajiannya. Bagi guru, mempelajari gerakan sebelum proses pembelajaran lebih mudah dan mendemonstrasikan kepada peserta didik juga lebih luwes. Bisa menghemat waktu dan dapat diputar berulang-ulang. Keras dan lemah suara dapat diatur. Guru dapat mengatur pergerakan gambar.

Dengan penggunaan media audiovisual guru dapat menampilkan beberapa video terkait gerak dasar pola langkah pencak silat, sehingga siswa dapat memperhatikan dengan seksama gerakan tersebut. Hasil penelitian ini didukung oleh hasil penelitian yang dilakukan oleh Hasibuan (2018) yang menunjukkan hasil setelah pemberian tindakan melalui penggunaan media audiovisual yang dilakukan pada penelitian diperoleh nilai rata-rata kelas menjadi 75,51 dengan ketuntasan belajar dari siswa meningkat sebesar $86,48 \%$. Hasil penelitian ini mempunyai hasil yang sama dengan penelitian yang sudah dipublikasikan. Sehingga penelitian ini mendukung penerapan media audio visual terhadap peningkatan hasil belajar peserta didik.

\section{KESIMPULAN}

Berdasarkan hasil penelitian dan pembahasan yang telah diuraikan di atas,maka peneliti menarik kesimpulan bahwa penerapan media audiovisual dapat meningkatkan hasil belajar gerak dasar pola langkah pencak silat pada siswa kelas V di SD Negeri Banjaran 2 Kediri Tahun Ajaran 2019/2020. Dimana penerapan media audiovisual mampu memudahkan guru dalam menjelaskan gerak pola langkah pencak silat dan siswa juga lebih mudah memahami penjelasan dari guru, sehingga pada saat pembelajaran di lapangan siswa lebih mudah untuk mempraktikkan gerakan pola langkah yang benar.

\section{DAFTAR PUSTAKA}

Dewi, K., \& Herman, Z. (2017). Pentingnya Media Pembelajaran. Jurnal Pendidikan Anak Usia Dini.

Ginting, A. (2010). Esensi Praktis Belajar dan Pembelajaran. Bandung: Humaniora.

Hasibuan, R. F. (2018). PENERAPAN MEDIA AUDIO VISUAL DALAM PEMBELAJARAN TENDANGAN BUSUR PENCAK SILAT UNTUK MENINGKATKAN HASIL BELAJAR SISWA KELAS XI. Seminar Nasional Pendidikan Olahraga, 568-575. Medan: UNIVERSITAS NEGERI MEDAN.

Jatmika, H. M. (2005). Pemanfaatan Media Visual dalam Menunjang Pembelajaran Pendidikan Jasmani di Sekolah Dasar. Jurnal Pendidikan Jasmani Indonesia.

Kurniawan, A. W. (2018). PENGEMBANGAN MEDIA AUDIO-VISUAL PENCAK SILAT SENI DENGAN MUSIK. Gelanggang Pendidikan Jasmani Indonesia. https://doi.org/10.17977/um040v2i1p10-17

Mashuri, H. (2017). Persepsi Siswa Terhadap Pembelajaran Guru Pendidikan Jasmani Di SMA Muhammadiyah Kediri. Jurnal SPORTIF: Jurnal Penelitian Pembelajaran. https://doi.org/10.29407/js_unpgri.v3i1.681

Mashuri, H. (2019). ANALISIS TINGKAT KENIKMATAN BERAKTIFITAS FISIK PESERTA DIDIK PENDIDIKAN JASMANI SEKOLAH MENENGAH KEJURUAN. Jp.Jok (Jurnal Pendidikan Jasmani, Olahraga Dan Kesehatan). https://doi.org/10.33503/jp.jok.v3i1.602

Mashuri, H., Puspitasari, I. C., \& Abadi, S. M. (2019). Pendidikan Jasmani dan Olahraga : Sebuah Pandangan Filosofi. Prosiding Seminar Pendidikan Dan Pembelajaran, 3, 383-390. 
Muhtar, T. (2017). PENERAPAN MODEL PEMBELAJARAN PENCAK SILAT BERBASIS KARAKTER. EduHumaniora I Jurnal Pendidikan Dasar Kampus Cibiru. https://doi.org/10.17509/eh.v8i1.5124

Mulyana. (2014). Pendidikan Pencak SIlat. Bandung: PT Remaja Rosdakarya.

Santoso, P. D. (2016). Pengaruh Media Audio Visual Terhadap Perkembangan Afektif Kognitif Dan Psikomotor Siswa Dalam Pembelajaran Permainan Futsal Di Smpn 1 Lembang. Jurnal Pendidikan Jasmani Dan Olahraga, 1(1).

Sudjana, N. (2006). Media Pengajaran. Bandung: Sinar Baru Algensindo.

Wati, E. (2016). Ragam Media Pembelajaran. Bandung: Humaniora.

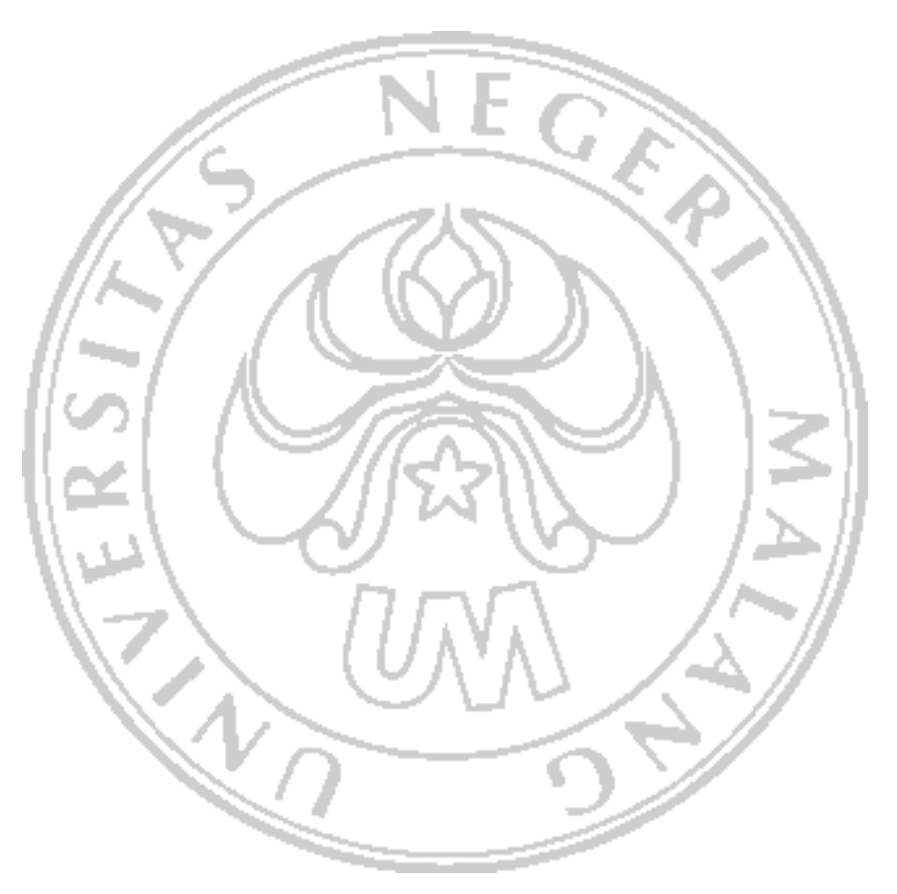

